\title{
Unmet needs of high-risk mothers reduce success of antiretroviral treatment in $\mathrm{HIV}$-infected infants
}

Effective prevention of mother-to-child transmission (PMTCT) programmes have dramatically reduced new paediatric HIV infections, and increasing access to antiretroviral therapy (ART) has substantially improved outcomes in infected children. ${ }^{[1-3]}$ However, unmet needs persist in paediatric HIV infection. ${ }^{[4]}$ In an ongoing study of early infant diagnosis and ART initiation following in utero transmission in KwaZulu-Natal Province, South Africa, we observe that the same factors predisposing to mother-to-child transmission (MTCT) in the current era of effective prevention are precisely those that militate against the success of ART for infected infants. Four cases are described to illustrate that the unmet needs of the high-risk mother have to be addressed urgently in order to achieve successful treatment of the infected child.

M1 is a 21-year-old mother who herself became HIV-infected as a result of MTCT. M1's mother died from HIV-related conditions when M1 was 10 years of age. Disclosure of M1's HIV status was at 13 years. Thereafter, adherence became problematic as she navigated adolescence without parental support. Now living with her partner's family, she feels unable to disclose her HIV status. At 18 years of age she had her first child, who died at 12 months, HIV status unknown. Two years later, she had a second child who was diagnosed as HIVinfected on the day of birth; ART was initiated at 20 hours of age. Because M1 needed to hide the medication, giving ART to her baby was erratic. The child's viral load (VL) became undetectable at 2 months of age, but rebounded the following month and has remained unstable since then.
M2 is a 17-year-old mother whose first child had been born 2 years previously with intrauterine HIV infection. M2 recently delivered her second baby at 28 weeks' gestation after a pregnancy without antenatal care. This child is also HIV-infected. M2 lives at home with her parents, having left secondary school prematurely. She has suffered from substance abuse and partner violence. M2 and the first HIV-infected child remain virologically unsuppressed, although the first child achieved an undetectable VL at 2 months of age. The VL of the second child is not known.

M3 is a 30-year-old married woman. She and her husband both have secondary education and are both employed. M3 first tested HIV-positive at 28 weeks' gestation and was told that taking ART would prevent the possibility of her transmitting the virus to her child. The baby's initial HIV test was indeterminate and the VL was undetectable. Repeat testing confirmed that the baby was HIVinfected. When told that the baby was infected, M3 said she had lost faith in ART, since she denied missing any doses during pregnancy. Subsequently, M3 has struggled to take her own therapy consistently or to administer ART to the infant, and both mother and child remain virally unsuppressed.

M4 is a 22-year-old mother who was orphaned in early childhood. Because of domestic violence at the hands of her extended family, she lived in a home of safety. She defaulted from ART prior to and during pregnancy owing to non-disclosure issues. She delivered a $1400 \mathrm{~g}$ baby at 29 weeks' gestation. The baby had an extended hospital stay because of multiple medical conditions associated with prematurity.

Table 1. Psychosocioeconomic and clinical factors influencing antiretroviral treatment outcome in four mother-child pairs following in utero HIV transmission

\begin{tabular}{|c|c|c|c|c|}
\hline Patient features & Case 1 & Case 2 & Case 3 & Case 4 \\
\hline \multicolumn{5}{|l|}{ Mother } \\
\hline Psychosocial/family & $\begin{array}{l}\text { - Loss of mother in } \\
\text { childhood, lack of family } \\
\text { support } \\
\text { - Dependence on partner } \\
\text { and partner's family for } \\
\text { accommodation } \\
\text { - Non-disclosure to } \\
\text { partner/partner's family } \\
\text { - First child at age } 18 \text { years }\end{array}$ & $\begin{array}{l}\text { - Left school early - lack of } \\
\text { education and life skills } \\
\text { - Substance abuse } \\
\text { - Partner violence } \\
\text { - First child at age } 15 \text { years } \\
\text { - Second child at age } 17 \\
\text { years }\end{array}$ & $\begin{array}{l}\text { - Stable, married, well } \\
\text { educated; patient and } \\
\text { husband employed } \\
\text { - The ability of ART } \\
\text { adherence to reduce the } \\
\text { risk of MTCT was not } \\
\text { fully explained }\end{array}$ & $\begin{array}{l}\text { - Orphaned in early } \\
\text { childhood, lived in home } \\
\text { of safety } \\
\text { - Domestic violence in } \\
\text { extended family } \\
\text { - Non-disclosure to } \\
\text { extended family prior to } \\
\text { delivery }\end{array}$ \\
\hline Clinical & $\begin{array}{l}\text { - Chronic HIV infection } \\
\text { from birth } \\
\text { - Declining CD } 4+\text { cell } \\
\text { count, persistent viraemia }\end{array}$ & $\begin{array}{l}\text { - No antenatal care } \\
\text { - Viraemia unsuppressed }\end{array}$ & $\begin{array}{l}\text { - VL } 350 \text { copies/mL } \\
\text { at delivery; latest VL } \\
9700 \text { copies } / \mathrm{mL}\end{array}$ & $\begin{array}{l}-\mathrm{VL} 330000 \text { copies } / \mathrm{mL} \\
\text { at delivery; latest VL } \\
<20 \text { copies } / \mathrm{mL} \text { at } 1 \text { month }\end{array}$ \\
\hline \multicolumn{5}{|l|}{ Child } \\
\hline Psychosocial/family & $\begin{array}{l}\text { - Sibling died at } 12 \text { months } \\
\text { of age } \\
\text { - Maternal non-disclosure, } \\
\text { non-adherence }\end{array}$ & $\begin{array}{l}\text { - Two children with HIV } \\
\text { infection } \\
\text { - Maternal non-disclosure, } \\
\text { non-adherence }\end{array}$ & $\begin{array}{l}\text { - Mother has lost faith in } \\
\text { ART } \\
\text { - Non-adherence despite } \\
\text { disclosure }\end{array}$ & $\begin{array}{l}\text { - Mother reconciled with } \\
\text { her family, facilitating } \\
\text { disclosure and ART } \\
\text { adherence }\end{array}$ \\
\hline Clinical & - Persistent viraemia & $\begin{array}{l}\text { - Younger sibling premature } \\
\text { at } 28 \text { weeks' gestation } \\
\text { - Persistent viraemia }\end{array}$ & $\begin{array}{l}\text { - Initial VL <100 copies/ } \\
\text { mL; VL } 1600 \text { copies/mL } \\
\text { at } 2 \text { months }\end{array}$ & $\begin{array}{l}\text { Premature at } 29 \text { weeks' } \\
\text { gestation, multiple } \\
\text { neonatal complications } \\
\text { - VL at birth } 3000 \text { copies/ } \\
\mathrm{mL} ; \mathrm{VL}<20 \text { copies } / \mathrm{mL} \text { at } \\
1 \text { month }\end{array}$ \\
\hline
\end{tabular}


The prolonged hospital stay provided an opportunity for intervention including social worker involvement, allowing reconciliation between M4 and her partner's family and disclosure of her HIV diagnosis to them. The baby initiated ART within the first 48 hours of life and reached an undetectable VL at 1 month of age. Both mother and baby have remained virologically suppressed to date without viral blips or rebound.

These four case studies illustrate several general features we have observed among the study cohort of in utero-infected infants and their mothers as a whole. In many cases the same factors that have destabilised the lives of mothers, and that contribute to HIV transmission, are those that interfere with effective treatment of HIV in the infants. In contrast, in the same setting in KwaZulu-Natal but 15 years ago, in the era prior to effective PMTCT, ART adherence levels of $\geq 95 \%$ and virological suppression rates of $100 \%$ were seen in infants at 1 year post ART. ${ }^{[5]}$ At that time, MTCT rates were high ${ }^{[2]}$ and there was no self-selection for non-adherence in those mothers.

The psychosocioeconomic factors set out in Table 1 play a critical role in determining ART adherence and therefore virological suppression in mother and child. Central among these is nondisclosure of HIV status to household members, as noted in other African studies. ${ }^{[4,6]}$ The struggle for survival experienced by many of these women takes priority over risking disclosure of HIV status, since in many cases the mother is entirely dependent on her partner for the basic needs of food and housing. Striking a balance between the two fundamental life issues of caring for an HIV-infected child and personal survival requires an open dialogue between healthcare providers and receivers of healthcare.

The fourth case described above illustrates what can be achieved in difficult circumstances. In this instance, the child was premature and initially unwell, requiring many weeks of hospital admission. This provided the opportunity for relationships to be established between social workers and the family, ultimately resulting in a successful outcome. In contrast, what is more typically observed is the lost opportunity to achieve rapid suppression of viraemia in newborns diagnosed in the first days of life. Indeed, in case 3, the infant had undetectable plasma viraemia initially, having received trans-placental ART. However, despite the parents - unusually - being married, educated and employed, the mother had become disillusioned with ART, having been poorly counselled during pregnancy.

In summary, in the era of effective PMTCT, the same psychosocioeconomic factors that predispose to mother-to-child transmission also substantially increase the likelihood of ART failure in infected infants. For this reason, maximal efforts now need to be invested in addressing the fundamental challenges faced by these high-risk mothers, since only then will the benefits of early infant diagnosis be fully realised.

Author contributions. Concept, writing and revision of article: ZM, VN, NB, JM, JR, KS, MA, TN, PG; data acquisition: ZM, VN, NB, JM, RB, MK, YG, JvL, CK, KC; study supervision: KS, MA, TN, PG; obtained funding: PG. Funding. The study was supported by a grant from the Wellcome Trust (WT104748MA) to PG.

\section{Zodumo Mvo}

Umkhuseli Innovation and Research Management, Pietermaritzburg, South Africa

zodumo@uirm.co.za

\section{Vuyokazi Ntlantsana}

School of Clinical Medicine, College of Health Sciences, University of KwaZulu-Natal, Durban, South Africa

\section{Nomonde Bengu}

Umkhuseli Innovation and Research Management, Pietermaritzburg, South Africa

\section{Jane Millar}

Umkhuseli Innovation and Research Management, Pietermaritzburg, South Africa; HIV Pathogenesis Programme, The Doris Duke Medical Research Institute, University of KwaZulu-Natal, Durban, South Africa; and Department of Paediatrics, University of Oxford, UK

\section{Julia Roider}

HIV Pathogenesis Programme, The Doris Duke Medical Research Institute, University of KwaZulu-Natal, Durban, South Africa; and Department of Paediatrics, University of Oxford, UK

\section{Roopesh Bhoola, Malini Krishna}

Edendale Hospital, Pietermaritzburg, South Africa

Yeney Graza, Jeroen van Lobenstein

Stanger Hospital, Durban, South Africa

\section{Constant Kapongo}

Lower Umfolozi Regional War Memorial Hospital, Empangeni, South Africa

\section{Chinniah Kogielambal}

Mahatma Gandhi Memorial Hospital, Durban, South Africa

\section{Ken Sprenger}

Umkhuseli Innovation and Research Management, Pietermaritzburg, South Africa

\section{Moherndran Archary}

Department of Paediatrics, School of Clinical Medicine, College of Health Sciences, University of KwaZulu-Natal, Durban, South Africa

\section{Thumbi Ndung'u}

HIV Pathogenesis Programme, The Doris Duke Medical Research Institute, University of KwaZulu-Natal, Durban, South Africa; Ragon Institute of MGH, MIT and Harvard, Cambridge, Massachusetts, USA; Africa Health Research Institute, Durban, South Africa; and Max Planck Institute for Infection Biology, Berlin, Germany

\section{Philip Goulder}

HIV Pathogenesis Programme, The Doris Duke Medical Research Institute, University of KwaZulu-Natal, Durban, South Africa; and Department of Paediatrics, University of Oxford, UK

\footnotetext{
1. Moodley P, Parboosing R, Moodley D. Reduction in perinatal HIV infections in KwaZulu-Natal, South Africa, in the era of more effective prevention of mother to child transmission interventions (2004 - 2012). J Acquir Immune Defic Syndr 2013;63(3):410-415. https://doi.org/10.1097/ QAI.0b013e3182926931

2. Prendergast AJ, Essajee S, Penazzato M. HIV and the millennium development goals. Arch Dis Child 2015;100(1):S48-S52. https://doi.org/10.1136/archdischild-2013-305548

3. Joint United Nations Programme on HIV/AIDS (UNAIDS). Ending AIDS: Progress towards the 90-90-90 targets. http://www.unaids.org/en/resources/documents/2017/20170720_Global_AIDS_

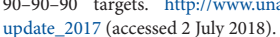

4. Orikiiriza J, Nakawesi J, Kikaire B, et al. Unmet needs persist in pediatric HIV programs: Lessons from selected case studies in Uganda. AIDS 2017;31(8):1196-1199. https://doi.org/10.1097/
from QAD. 000000000000143

5. Prendergast A, Mphatswe W, Tudor-Williams G, et al. Early virological suppression with three-class antiretroviral therapy in HIV-infected African infants. AIDS 2008;22(11):1333-1343. https://doi. org/10.1097/QAD.0b013e32830437df

6. Frigati L, Wynberg E, Maritz J, Holgate S, Cotton MF, Rabie H. Antiretroviral treatment initiated in the first month of life. Pediatr Infect Dis J 2017;36(6):584-587. https://doi.org/10.1097/ INF.0000000000001504
}

S Afr Med J 2018;108(8):609-610. DOI:10.7196/SAMJ.2018.v108i8.13376 